\title{
PREFERENSI KONSUMEN TERHADAP FAKTOR-FAKTOR PENENTU KEPUASAN KONSUMEN DALAM PENGAMBILAN KEPUTUSAN PEMBELIAN PERUMAHAN BERSUBSIDI DI KARAWANG
}

\author{
Budi Anthony ${ }^{1}$, Nurahma Tresani ${ }^{2}$, Ricky Pittra Halim ${ }^{3}$ \\ ${ }^{1}$ Alumni Magister Teknik Perencanaan, Universitas Tarumanagara, Jakarta \\ ${ }^{2}$ Dosen Pembimbing Pertama Magister Teknik Perencanaan, Universitas Tarumanagara, Jakarta \\ ${ }^{3}$ Dosen Pembimbing Kedua Magister Teknik Perencanaan, Universitas Tarumanagara, Jakarta \\ Email: antonyba123@gmail.com
}

\begin{abstract}
ABSTRAK
In the conditions of competition among subsidized housing developers, attention should be given to the determinants of consumer satisfaction in the purchasing process of subsidized housing products, especially in Karawang. The low price of land in Karawang is expected to stimulate developers to build subsidized housing. Million House Program from Kemenpera provides a very low 5\% price subsidy and a constant interest rate over the tenor of credit. However, this does not automatically make consumers buy subsidized houses built in Karawang. Therefore, the authors conduct research by distributing questionnaires directly to residents in Taman Palumbon Asri housing, Bhumi Baru Indah Persada and Griya Indah which is all located in Karawang. The purpose of this research is to identify the influence of price factor, location, condition of environment and condition of building to decision making of purchase and to identify consumer satisfaction toward subsidized housing, with sample 3 subsidized housing in Karawang. Writer uses Index Compatibility Level to measure level of satisfaction and level of interest for each housing, and then analyze them by considering each factors (location, price, quality of building, and environmental factors).

Keywords: Price, Location, Building, Environment, Consumer Satisfaction, Purchasing Decision, Index Compatibility Level
\end{abstract}

\section{PENDAHULUAN}

Banyaknya jumlah masyarakat dibandingkan dengan kesediaan rumah menyebabkan adanya backlog perumahan. Pemerintah melalui Perum Perumnas (Perusahaan Umum Perumahan Nasional) memprogramkan Program Sejuta Rumah dan Seribu Menara. Di dalam program ini terdapat kebijakan penyaluran subsidi melalui Skema Pembiayaan KPR Sejahtera Fasilitas Likuiditas Pembiayaan Perumahan (FLPP) dan KPR SSB (Subsidi Selisih Bunga), sesuai dengan batasan harga yang diatur dalam Permenpera No. 3/2014 dengan penentuan kenaikan harga 5\% per tahun yang diatur melalui Peraturan Menteri Keuangan No. 113/PMK.03/2014 dengan masa cicilan atau tenor waktu yang diberikan sampai dengan 20 tahun, uang muka ringan, bebas PPN serta bebas premi asuransi dan asuransi kebakaran. Program Sejuta Rumah (PSR) ini juga mendapatkan dukungan dari para developer swasta yang ikut menanggung beban pemerintah dalam menyediakan rumah rakyat. Salah satu kawasan pengembangan yang sedang banyak dilirik oleh pengembang swasta yaitu Karawang. Harga lahan yang masih terhitung murah dibandingkan Bekasi dan Cikarang, serta populasi yang semakin bertambah seiring dengan masuknya perusahaan dalam negeri maupun multinasional yang mengembangkan bisnis di Karawang, membuat pasar perumahan di Karawang semakin bagus, salah satunya adalah perumahan bersubsidi. Tujuan penelitian ini adalah untuk mengetahui tentang pengaruh faktor lokasi, harga, desain dan kualitas bangunan serta lingkungan terhadap kepuasan konsumen dalam pengambilan keputusan pembelian Rumah Sederhana bersubsidi di Kota Karawang. Ruang lingkup pembahasan berisi mengenai batasan materi yang akan dibahas adalah permasalahan yang menjadi faktor penyebab kurangnya minat dan keputusan konsumen untuk membeli perumahan bersubsidi Rumah Sederhana di kota Karawang. Permasalahan tersebut dilihat dari persepsi konsumen tehadap faktor-faktor penentu kepuasan konsumen yang telah ditentukan yaitu faktor lokasi, harga, desain dan kualitas bangunan, serta kondisi lingkungan. 
Sedangkan, ruang lingkup wilayah dibatasi di Kabupaten Karawang, tepatnya di 3 perumahan yaitu Bhumi Indah Persada, Taman Palumbon Asri, serta Griya Indah.

\section{MATERI DAN METODE}

Terdapat variabel endogen (terikat/ dependen), yaitu: keputusan pembelian rumah sederhana oleh konsumen yang terjadi di Kota Karawang. Keputusan pembelian rumah tersebut diukur dari tingkat kepuasan dan tingkat kepentingan faktor lokasi, harga, desain dan kualitas bangunan, serta lingkungan. Sedangkan, variabel eksogen (bebas/ independen), yaitu:

1. Profil penghuni (identitas penghuni, struktur keluarga, pekerjaan, kesejahteraan keluarga, tingkat pendidikan)

2. Harga

- Kesesuaian harga dengan daya beli

- Kesesuaian harga dengan cicilan terjangkau yang sesuai kemampuan

- Kesesuaian harga melalui uang muka yang ringan

- Kesesuaian harga melalui pajak dan biaya transaksi yang terjangkau

3. Lokasi

- Jarak ke pusat kota

- Jarak ke tempat kerja

- Jarak ke pusat kegiatan

- Kemudahan transportasi

- Tidak banjir

4. Desain dan kualitas bangunan

- Desain dan tampak depan bangunan

- Denah bangunan

- Spesifikasi bangunan

- Kualitas pengerjaan

5. Lingkungan

- Keamanan lingkungan\

- Keasrian dan kenyamanan lingkungan

- Lahan perumahan luas dan jalan lebar

- Perumahan sudah ramai

- Tetangga-tetangga dikenal dengan baik

Metode penelitian yang digunakan dalam penelitian ini adalah metode kuantitatif deskriptif menggunakan kuesioner, dengan cara skoring untuk setiap variabel faktor. Di mana, skor 1 adalah sangat tidak puas untuk penilaian tingkat kepuasan dan sangat tidak penting untuk penilaian tingkat kepentingan. Sebaliknya, skor 4 adalah sangat puas untuk penilaian tingkat kepuasan dan sangat penting untuk penilaian tingkat kepentingan.

\section{a. Populasi}

- Bhumi Baru Indah Persada: luas 11.6 ha dengan jumlah 1060 unit rumah

- Taman Palumbon Asri: luas 8 ha dengan jumlah 600 unit rumah

- Griya Indah Cikampek:luas 10 ha dengan jumlah 1200 unit rumah

\section{b. Teknik Sampling}

Teknik sampling yang digunakan adalah teknik probability sampling, di mana semua anggota dari populasi mempunyai kesempatan yang sama untuk dipilih. Metode probability sampling yang digunakan dalam penelitian ini adalah purpose sampling atau 
stratified random sampling, di mana dalam teknik ini dipilih sampel responden yang sesuai dengan target yang dituju.

\section{c. Ukuran Sampel Penelitian}

Menurut Roscoe dalam Fundamental Research Statistics for the Behavioral Sciences (1975), bila dalam penelitian akan melakukan analisis dengan multivariat (korelasi atau regresi ganda misalnya), maka jumlah sampel minimal 10 kali dari jumlah variabel yang diteliti. Jika variabel yang diteliti adalah 4, yaitu faktor lokasi, harga, desain dan kualitas bangunan, serta lingkungan, maka jumlah sampel minimal adalah 40 untuk setiap perumahan. sehingga total 120 responden. Responden yang dimaksud di sini adalah penghuni perumahan-perumahan tersebut.

Analisa dilakukan secara deskriptif pada hasil olahan data yang menunjukkan tingkat kepuasan responden, tingkat kepentingan responden, dan Tingkat Kepuasan Indeks (TKI). Setelah itu, juga dilakukan analisa kuadran Likert untuk mengetahui faktor-faktor apa yang menjadi menjadi prioritas, faktor yang tidak menjadi prioritas, faktor yang sudah baik dan perlu dipertahankan, serta faktor yang terlalu berlebihan padahal bukan merupakan prioritas responden.

\section{HASIL DAN DISKUSI}

Dari data deskriptif diketahui umumnya profile dominan penghuni perumahan sederhana di tiga perumahan tersebut respondennya berusia $20-40$ tahun ( $51 \%$ ), telah berkeluarga atau sudah menikah ( $71 \%$ ) dan jumlah keluarga 3 orang SMA ( $53 \%$ ) .Dari segi tingkat pendidikan yang paling dominan SMA sebesar $76 \%$, pekerjaan sebagai pegawai swasta atau buruh pabrik sebesar $92 \%$, dengan rata pengeluaran makan dibawah Rp 1,5 juta sebesar $49 \%$ dengan rata rata penghasilan sesuai tingkat UMR sebesar Rp 4 juta rupiah per kepala keluarga . Sebagai alat transportasi keluarga umunya sepada motor sebesar $92 \%$.

\section{Analisis Rata-Rata Tingkat Kepuasan Penghuni 1a. Bhumi Indah Persada}

Untuk faktor lokasi, tingkat kepuasan tertinggi responden adalah faktor tidak banjir, diikuti dengan kedekatan jarak ke tempat kerja. Faktor yang memiliki skoring paling kecil adalah faktor jarak ke pusat kota. Secara lokasi, perumahan ini dekat dengan pintu tol dan kawasan industri namun cukup jauh ke pusat kota. Untuk faktor desain dan kualitas bangunan, tingkat kepuasan tertinggi responden adalah kualitas pengerjaan bangunan, kemudian diikuti dengan desain tampak depan bangunan. Namun, rata-rata skoring untuk faktor ini semua di atas 3 . Untuk faktor harga, skor tertinggi adalah uang muka murah, kemudian diikuti dengan cicilan sesuai kemampuan. Ini menunjukkan bahwa program promo uang muka yang dilakukan developer berhasil. Untuk faktor lingkungan, skor tertinggi adalah keamanan lingkungan, kemudian diikuti dengan lingkungan nyaman dan asri.

\section{1b. Taman Palumbon Asri}

Untuk faktor lokasi, tingkat kepuasan tertinggi responden adalah faktor kedekatan jarak ke tempat kerja, kemudian diikuti dengan tidak banjir. Faktor-faktor lokasi lainnya juga menunjukkan skoring yang bagus, yaitu semuanya di atas 3. Untuk faktor desain dan kualitas bangunan, skor tertinggi adalah kualitas pengerjaan bangunan. Faktor desain tampak depan rumah justru mendapatkan skoring terkecil dibandingkan yang lain. Untuk faktor harga, skor tertinggi adalah pajak dan biaya jual beli murah, diikuti dengan cicilan sesuai kemampuan dan uang muka ringan. Untuk faktor lingkungan, skor tertinggi adalah lahan luas dan jalan perumahan lebar, diikuti dengan lingkungan asri dan nyaman. 


\section{1c. Griya Indah}

Untuk faktor lokasi, tingkat kepuasan tertinggi responden adalah faktor kedekatan dengan lokasi kerja, diikuti dengan tidak banjir. Untuk faktor desain dan kualitas bangunan, skor tertinggi adalah faktor kualitas pengerjaan, diikuti dengan desain tampak depan rumah yang bagus. Untuk faktor harga, skor tertinggi adalah faktor harga rumah sesuai kemampuan, diikuti dengan faktor uang muka murah. Untuk faktor lingkungan, skor tertinggi adalah faktor keamanan lingkungan diikuti dengan lingkungan yang nyaman dan asri.

\section{Analisis Rata-Rata Tingkat Kepentingan Penghuni \\ 2a. Bhumi Indah Persada}

Untuk faktor lokasi, tingkat kepentingan tertinggi responden adalah kemudahan transportasi, diikuti dengan tidak banjir. Sedangkan faktor jarak ke pusat kota dianggap relatif lebih tidak penting dibandingkan faktor-faktor lokasi yang lain. Hampir semua faktor lokasi ini mendapatkan skoring di atas 3, artinya responden menganggap semua variabel faktor lokasi itu faktor penting. Untuk faktor desain dan kualitas bangunan, skor tertinggi adalah kualitas pengerjaan diikuti dengan desain tampak depan. Sedangkan, denah dianggap relatif tidak penting. Jika dianalisa, hal ini disebabkan variasi denah yang dapat dilakukan pada tipe rumah RSS sangat terbatas karena ukuran yang kecil. Untuk faktor harga, skor tertinggi adalah cicilan per bulan sesuai kemampuan dan uang muka murah. Untuk faktor lingkungan, skor tertinggi adalah keamanan lingkungan, diikuti dengan lingkungan asri dan nyaman.

\section{2b. Taman Palumbon Asri}

Untuk faktor lokasi, tingkat kepentingan tertinggi responden adalah kedekatan tempat kerja, kemudahan transportasi, dan tidak banjir dengan skoring yang sama besar, atau semua dianggap penting. Untuk faktor desain dan kualitas bangunan, skor tertinggi adalah kualitas pengerjaan, diikuti dengan spesifikasi bangunan. Untuk faktor harga, skor tertinggi adalah cicilan per bulan sesuai kemampuan, lalu uang muka ringan. Untuk faktor lingkungan, skor tertinggi adalah keamanan lingkungan diikuti dengan lingkungan yang nyaman dan asri.

\section{2c. Griya Indah}

Untuk faktor lokasi, tingkat kepentingan tertinggi responden adalah kedekatan jarak ke tempat kerja, diikuti dengan tidak banjir. Untuk faktor desain dan kualitas bangunan, skor tertinggi adalah kualitas pengerjaan, diikuti tampak depan rumah. Untuk faktor harga, skor tertinggi adalah cicilan per bulan sesuai kemampuan, diikuti uang muka murah. Untuk faktor lingkungan, skor tertinggi adalah keamanan lingkungan, diikuti lingkungan asri dan nyaman.

\section{Analisis Perbandingan Tingkat Kepuasan dengan Kepentingan}

Tabel 1. Tingkat Kepentingan Indeks (TKI) Bhumi Indah Persada

\begin{tabular}{|c|l|c|c|c|c|c|c|}
\hline No. & $\begin{array}{c}\text { Faktor- } \\
\text { faktor }\end{array}$ & $\begin{array}{c}\text { Tingkat } \\
\text { Kepentingan }\end{array}$ & $\begin{array}{c}\text { Tingkat } \\
\text { Kepuasan }\end{array}$ & $\begin{array}{c}\text { Rata-rata } \\
\text { Tingkat } \\
\text { Kepuasan } \\
\text { (a) }\end{array}$ & $\begin{array}{c}\text { Rata-rata } \\
\text { Tingkat } \\
\text { Kepentingan } \\
\text { (b) }\end{array}$ & $\begin{array}{c}\text { TKI } \\
\mathbf{a} / \mathbf{b} * \mathbf{1 0 0} \\
\mathbf{\%}\end{array}$ & Kesimpulan \\
\hline 1 & Lokasi & 135,60 & 128,00 & 3.2 & 3.39 & $94 \%$ & Kurang Memuaskan \\
\hline 2 & $\begin{array}{l}\text { Lesain dan } \\
\text { Kualitas } \\
\text { Bangunan }\end{array}$ & 124,75 & 128,75 & 3.22 & 3.12 & $103 \%$ & Sangat Memuaskan \\
\hline 3 & Harga & 139,00 & 135,20 & 3.38 & 3.48 & $97 \%$ & Kurang Memuaskan \\
\hline 4 & Lingkungan & 122,60 & 125,00 & 3.13 & 3.07 & $102 \%$ & Memuaskan \\
\hline
\end{tabular}


Nilai TKI paling tinggi adalah faktor desain dan kualitas bangunan kemudian diikuti faktor lingkungan, sementara nilai TKI paling rendah adalah faktor lokasi. Nilai TKI rata-rata untuk Perumahan Bhumi Baru Indah Persada ini sebesar 99\% (di bawah 100\%), yang artinya masih belum sesuai ekspektasi konsumen.

Tabel 2. Tingkat Kepentingan Indeks (TKI) Taman Palumbon Asri

\begin{tabular}{|c|l|c|c|c|c|c|c|}
\hline No. & Faktor-faktor & $\begin{array}{c}\text { Tingkat } \\
\text { Kepenting } \\
\text { an }\end{array}$ & $\begin{array}{c}\text { Tingkat } \\
\text { Kepuasan }\end{array}$ & $\begin{array}{c}\text { Rata-rata } \\
\text { Tingkat } \\
\text { Kepuasan } \\
(\mathbf{a})\end{array}$ & $\begin{array}{c}\text { Rata-rata } \\
\text { Tingkat } \\
\text { Kepentingan } \\
(\mathbf{b})\end{array}$ & $\begin{array}{c}\text { TKI } \\
\mathbf{a} / \mathbf{b} * \mathbf{1 0 0} \\
\mathbf{\%}\end{array}$ & Kesimpulan \\
\hline 1 & Lokasi & 135,60 & 142,80 & 3.57 & 3.39 & $105 \%$ & Sangat Memuaskan \\
\hline 2 & $\begin{array}{l}\text { Desain dan } \\
\text { Kualitas } \\
\text { Bangunan }\end{array}$ & 119,25 & 129,00 & 3.23 & 2.98 & $108 \%$ & Sangat Memuaskan \\
\hline 3 & Harga & 137,60 & 139,40 & 3.49 & 3.44 & $101 \%$ & Memuaskan \\
\hline 4 & Lingkungan & 125,00 & 132,80 & 3.32 & 3.13 & $106 \%$ & Sangat Memuaskan \\
\hline \multicolumn{7}{|c|}{ RATA-RATA } \\
\hline
\end{tabular}

Nilai TKI yang paling tinggi adalah faktor desain dan kualitas bangunan diikuti faktor lingkungan dan lokasi. Nilai TKI rata-rata untuk Perumahan Taman Palumbon Asri ini sangat tinggi, yaitu $105 \%$ yang artinya Perumahan ini sudah sesuai harapan, bahkan melebihi ekspektasi konsumen.

Tabel 3. Tingkat Kepentingan Indeks (TKI) Griya Indah

\begin{tabular}{|c|l|c|c|c|c|c|c|}
\hline No. & Faktor-faktor & $\begin{array}{c}\text { Tingkat } \\
\text { Kepenting } \\
\text { an }\end{array}$ & $\begin{array}{c}\text { Tingkat } \\
\text { Kepuasan }\end{array}$ & $\begin{array}{c}\text { Rata-rata } \\
\text { Tingkat } \\
\text { Kepuasan } \\
(\mathbf{a})\end{array}$ & $\begin{array}{c}\text { Rata-rata } \\
\text { Tingkat } \\
\text { Kepentingan } \\
(\mathbf{b})\end{array}$ & $\begin{array}{c}\text { TKI } \\
\mathbf{= a / b * 1 0 0} \\
\mathbf{\%}\end{array}$ & Kesimpulan \\
\hline 1 & Lokasi & 135,60 & 142,80 & 3.57 & 3.39 & $105 \%$ & Sangat Memuaskan \\
\hline 2 & $\begin{array}{l}\text { Desain dan } \\
\text { Kualitas } \\
\text { Bangunan }\end{array}$ & 119,25 & 129,00 & 3.23 & 2.98 & $108 \%$ & Sangat Memuaskan \\
\hline 3 & Harga & 137,60 & 139,40 & 3.49 & 3.44 & $101 \%$ & Memuaskan \\
\hline 4 & Lingkungan & 125,00 & 132,80 & 3.32 & 3.13 & $106 \%$ & Sangat Memuaskan \\
\hline \multicolumn{7}{|c|}{ RATA-RATA } \\
\hline
\end{tabular}

Nilai TKI yang paling tinggi adalah faktor desain dan kualitas bangunan, diikuti oleh faktor harga. Nilai TKI rata-rata untuk Perumahan Griya Indah ini yaitu 97\% (di bawah 100\%) yang artinya Perumahan Griya Indah Cikampek masih belum sesuai ekspektasi konsumen.

\section{Analisis Kuadran Likert}

Pada Diagram Kartesius, Nomor 1 menggambarkan faktor lokasi, nomor 2 menggambarkan faktor desain dan kualitas bangunan, nomor 3 menggambarkan faktor harga, dan nomor 4 menggambarkan faktor lingkungan. Sumbu x menunjukkan tingkat kepuasan, yang artinya semakin ke kanan maka konsumen semakin puas. Sementara, sumbu y menunjukkan tingkat kepentingan, yang artinya semakin ke atas maka semakin dianggap penting oleh konsumen. Dari tingkat kepentingan dan kepuasan tersebut dapat dibagi menjadi 4 kuadran, di mana kuadran A artinya Prioritas Utama yang harus diperhatikan developer, kuadran B artinya Sudah Bagus dan harus dipertahankan, kuadran C artinya Prioritas Rendah, serta kuadran D artinya Berlebihan. 


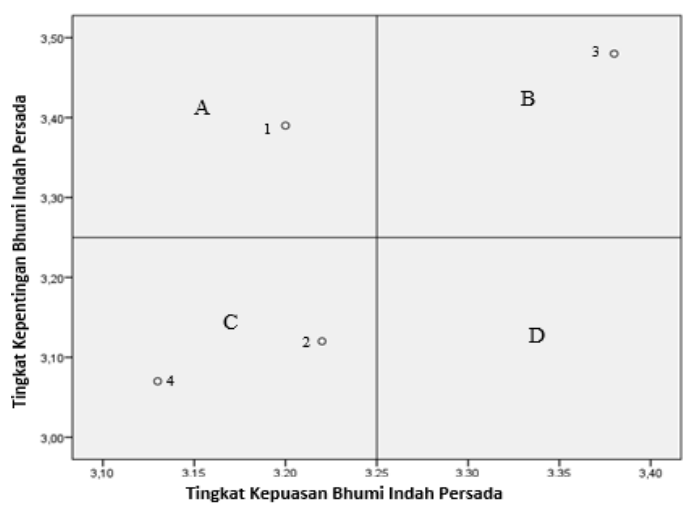

Gambar 1. Analisa Kuadran Bhumi Baru Indah Persada

Dari Gambar 1 terlihat bahwa developer perlu melakukan peningkatan pada faktor lokasi, sebab menurut Diagran Kartesius di atas, faktor lokasi dianggap sangat penting namun masih memiliki tingkat kepuasan relatif rendah. Sedangkan prioritas kedua, developer perlu melakukan peningkatan pada faktor desain dan kualitas bangunan serta faktor lingkungan. Namun, hal ini tidak menjadi prioritas karena walaupun kedua faktor ini memiliki tingkat kepuasan relatif rendah tetapi tingkat kepentingan juga relatif rendah. Untuk peningkatan kinerja, karena letak lokasi sudah given, maka yang dapat dilakukan adalah dengan memberikan kemudahan transportasi ke lokasi serta developer harus benar-benar mengantisipasi supaya lokasi tidak banjir.

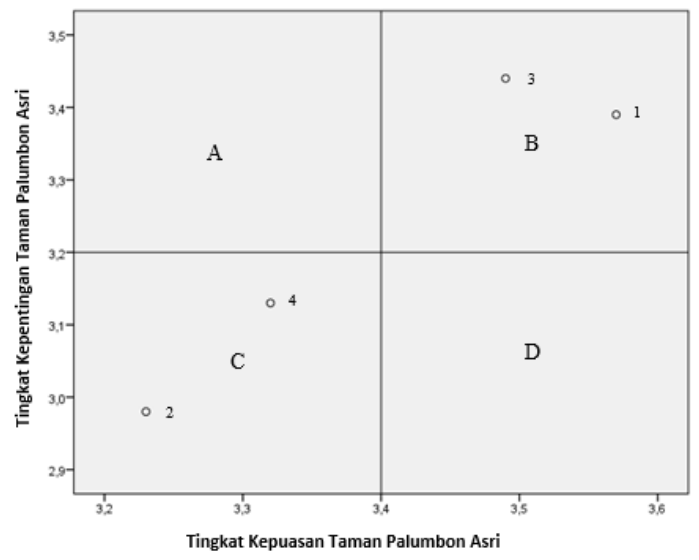

Gambar 2. Analisa Kuadran Taman Palumbon Asri

Dari Gambar 2 terlihat bahwa developer tidak perlu melakukan peningkatan khusus sebagai prioritas utama, tidak ada faktor yang masih memiliki tingkat kepentingan tinggi namun tingkat kepuasan rendah (kuadran A). Sedangkan prioritas kedua namun tidak wajib, developer dapat melakukan peningkatan pada faktor desain dan kualitas bangunan, serta faktor lingkungan.

Dari Gambar 3 terlihat bahwa developer perlu melakukan peningkatan pada faktor lokasi sebagai priorotas utama (kuadran A), sebab faktor lokasi dianggap sangat penting namun masih memiliki tingkat kepuasan relatif rendah. Sedangkan prioritas kedua, developer perlu melakukan peningkatan pada faktor lingkungan. 


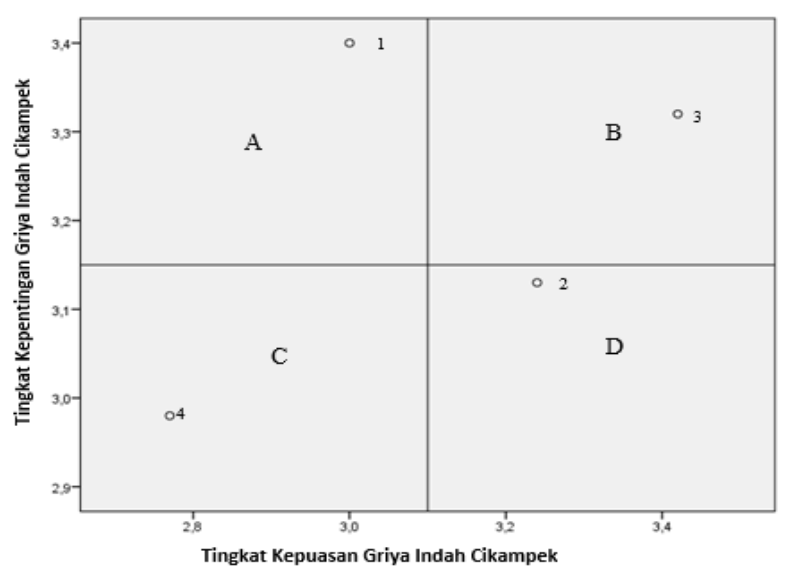

Gambar 3. Analisa Kuadran Griya Indah

\section{Analisa Gabungan Tingkat Kesesuaian Indeks}

Tabel 4. Analisa Gabungan TKI untuk Faktor Lokasi

\begin{tabular}{|c|c|c|c|c|c|c|c|c|c|c|c|c|c|c|c|}
\hline \multirow{2}{*}{\multicolumn{2}{|c|}{ Faktor Lokasi }} & \multicolumn{5}{|c|}{ Tingkat Kepuasan } & \multirow{2}{*}{$\begin{array}{c}\text { Rata Rata } \\
\text { Tingkat } \\
\text { Kepuasan }\end{array}$} & \multicolumn{5}{|c|}{ Tingkat Kepentingan } & \multirow{2}{*}{\begin{tabular}{|c|} 
Rata Rata \\
Tingkat \\
Kepenting \\
\end{tabular}} & \multirow[b]{2}{*}{ TKI } & \multirow[b]{2}{*}{$\begin{array}{r}\text { Bobot } \\
(\%)\end{array}$} \\
\hline & & $\begin{array}{c}\text { Jarak ke } \\
\text { Pusat Kota } \\
\end{array}$ & \begin{tabular}{c|} 
Tempat \\
Kerja
\end{tabular} & $\begin{array}{c}\text { Jarak ke Pusat } \\
\text { Kegiatan }\end{array}$ & \begin{tabular}{|c|} 
Kemudahanan \\
Tranportasi \\
\end{tabular} & $\begin{array}{l}\text { Tidak } \\
\text { banjir }\end{array}$ & & \begin{tabular}{|c|} 
Jarak ke \\
Pusat Kota
\end{tabular} & $\begin{array}{c}\text { Tempat } \\
\text { Kerja }\end{array}$ & $\begin{array}{c}\text { Jarak ke Pusat } \\
\text { Kegiatan }\end{array}$ & $\begin{array}{c}\text { Kemudahanan } \\
\text { Tranportasi } \\
\end{array}$ & $\begin{array}{l}\text { Tidak } \\
\text { banjir }\end{array}$ & & & \\
\hline \multirow[b]{2}{*}{ BIP } & Jumlah R 40 & 116 & 129 & 124 & 124 & 147 & \multirow[b]{2}{*}{3.20} & 117 & 142 & 130 & 146 & 143 & \multirow[b]{2}{*}{3.39} & \multirow[b]{2}{*}{$94 \%$} & \multirow[b]{2}{*}{$33 \%$} \\
\hline & Rata 2 & 2.90 & 3.23 & 3.10 & 3.10 & 3.68 & & 2.93 & 3.55 & 3.25 & 3.65 & 3.58 & & & \\
\hline \multirow[b]{2}{*}{ Palumbon } & Jumlah R 40 & 131 & 151 & 139 & 145 & 148 & \multirow{2}{*}{3.57} & 112 & 144 & 134 & 144 & 144 & \multirow{2}{*}{3.39} & \multirow[b]{2}{*}{$105 \%$} & \multirow{2}{*}{$37 \%$} \\
\hline & Rata 2 & 3.28 & 3.78 & 3.48 & 3.63 & 3.70 & & 2.80 & 3.60 & 3.35 & 3.60 & 3.60 & & & \\
\hline \multirow{2}{*}{ Griya Indah } & Jumlah R 40 & 100 & 146 & 106 & 109 & 139 & \multirow{2}{*}{3.00} & 120 & 150 & 121 & 144 & 145 & \multirow{2}{*}{3.40} & \multirow{2}{*}{$88 \%$} & \multirow{2}{*}{$31 \%$} \\
\hline & Rata 2 & 2.50 & 3.65 & 2.65 & 2.73 & 3.48 & & 3.00 & 3.75 & 3.03 & 3.60 & 3.63 & & & \\
\hline \multirow{2}{*}{ Gabungan } & Total R 120 & 347 & 426 & 369 & 378 & 434 & \multirow{2}{*}{3.26} & 349 & 436 & 385 & 434 & 432 & \multirow{2}{*}{3.39} & \multirow{2}{*}{$96 \%$} & \multirow{2}{*}{$100 \%$} \\
\hline & Rata 2 & 2.89 & 3.55 & 3.08 & 3.15 & 3.62 & & 2.91 & 3.63 & 3.21 & 3.62 & 3.60 & & & \\
\hline
\end{tabular}

Dari seluruh responden, rata-rata nilai TKI lokasi masih di bawah $100 \%$. Hal ini menunjukan konsumen masih belum puas terhadap lokasi perumahan tersebut. Namun, untuk Perumahan Taman Palumbon Asri memiliki nilai TKI di atas rata rata yaitu 105\%, lebih besar dari rata rata TKI di ketiga perumahan yaitu 96\%. Hal ini berarti secara lokasi Taman Palumbon Asri lebih baik dimata konsumen dibanding kedua perumahan lainnya.

Tabel 5. Analisa Gabungan TKI untuk Faktor Desain dan Kualitas Bangunan

\begin{tabular}{|c|c|c|c|c|c|c|c|c|c|c|c|c|c|}
\hline \multirow{2}{*}{\multicolumn{2}{|c|}{$\begin{array}{c}\text { Faktor Desain dan } \\
\text { Kualitas Bangunan } \\
\text { Rumah }\end{array}$}} & \multicolumn{4}{|c|}{ Tingkat Kepuasan } & \multirow[b]{2}{*}{$\begin{array}{c}\text { Rata Rata } \\
\text { Tingkat } \\
\text { Kepuasan }\end{array}$} & \multicolumn{4}{|c|}{ Tingkat Kepentingan } & \multirow[b]{2}{*}{$\begin{array}{l}\text { Rata Rata } \\
\text { Tingkat } \\
\text { Kepentingan }\end{array}$} & \multirow[b]{2}{*}{ TKI } & \multirow[b]{2}{*}{$\begin{array}{c}\text { Bobot } \\
\text { (\%) }\end{array}$} \\
\hline & & $\begin{array}{c}\text { Tampak Depan } \\
\text { Rumah }\end{array}$ & $\begin{array}{l}\text { Denah } \\
\text { Rumah }\end{array}$ & $\begin{array}{l}\text { Spesifikasi } \\
\text { Bangunan }\end{array}$ & $\begin{array}{l}\text { Kualitas } \\
\text { Pengerjaan }\end{array}$ & & $\begin{array}{c}\text { Tampak } \\
\text { Depan } \\
\text { Rumah }\end{array}$ & $\begin{array}{l}\text { Denah } \\
\text { Rumah }\end{array}$ & $\begin{array}{l}\text { Spesifikasi } \\
\text { Bangunan }\end{array}$ & $\begin{array}{c}\text { Kualitas } \\
\text { Pengerjaan }\end{array}$ & & & \\
\hline \multirow{2}{*}{ BIP } & Jumlah & 134 & 124 & 120 & 137 & \multirow{2}{*}{2.58} & 128 & 114 & 121 & 136 & \multirow[b]{2}{*}{2.50} & \multirow[b]{2}{*}{$103 \%$} & \multirow{2}{*}{$33 \%$} \\
\hline & Rata 2 & 3.350 & 3.100 & 3.000 & 3.425 & & 3.200 & 2.850 & 3.025 & 3.400 & & & \\
\hline \multirow{2}{*}{ Palumbon } & Jumlah & 119 & 131 & 129 & 137 & \multirow{2}{*}{2.58} & 110 & 110 & 126 & 131 & \multirow{2}{*}{2.39} & \multirow{2}{*}{$108 \%$} & \multirow{2}{*}{$34 \%$} \\
\hline & Rata 2 & 2.98 & 3.28 & 3.23 & 3.43 & & 2.75 & 2.75 & 3.15 & 3.28 & & & \\
\hline \multirow{2}{*}{ Griya Indah } & Jumlah & 136 & 124 & 121 & 138 & \multirow{2}{*}{2.60} & 130 & 114 & 121 & 136 & \multirow{2}{*}{2.51} & \multirow{2}{*}{$104 \%$} & \multirow{2}{*}{$33 \%$} \\
\hline & \begin{tabular}{|l|} 
Rata 2 \\
\end{tabular} & 3.40 & 3.10 & 3.03 & 3.45 & & 3.25 & 2.85 & 3.03 & 3.40 & & & \\
\hline \multirow{2}{*}{ Gabungan } & Total & 389 & 379 & 370 & 412 & \multirow{2}{*}{2.58} & 368 & 338 & 368 & 403 & \multirow{2}{*}{2.46} & \multirow{2}{*}{$105 \%$} & \multirow{2}{*}{$100 \%$} \\
\hline & Rata 2 & 3.24 & 3.16 & 3.08 & 3.43 & & 3.07 & 2.82 & 3.07 & 3.36 & & & \\
\hline
\end{tabular}

Dari seluruh responden, rata-rata nilai TKI faktor desain dan kualitas bangunan di atas $100 \%$. Hal ini menunjukan konsumen puas terhadap desain dan kualitas bangunan di ketiga perumahan tersebut.

Tabel 6. Analisa Gabungan TKI untuk Faktor Harga

\begin{tabular}{|c|c|c|c|c|c|c|c|c|c|c|c|c|c|c|c|}
\hline \multirow{2}{*}{\multicolumn{2}{|c|}{ Faktor Harga }} & \multicolumn{5}{|c|}{ Tingkat Kepuasan } & \multirow[b]{2}{*}{$\begin{array}{c}\text { Rata } \\
\text { Ratatingkat } \\
\text { Kepuasan }\end{array}$} & \multicolumn{5}{|c|}{ Tingkat Kepentingan } & \multirow[b]{2}{*}{$\begin{array}{c}\text { Rata Rata } \\
\text { Tingkat } \\
\text { Kepentingan }\end{array}$} & \multirow[b]{2}{*}{ TKI } & \multirow[b]{2}{*}{ Bobot (\%) } \\
\hline & & $\begin{array}{c}\text { Harga Rumah } \\
\text { Sesuai }\end{array}$ & \begin{tabular}{|l|} 
Harga Rumah \\
Lebih Murah
\end{tabular} & Uang Muka & \begin{tabular}{|c|} 
Cicilan Per \\
Bulan Sesuai
\end{tabular} & Pajak dan Biaya & & $\begin{array}{c}\text { Harga Rumah } \\
\text { Sesuai }\end{array}$ & $\begin{array}{c}\text { Harga Rumah Lebih } \\
\text { Murah daripada }\end{array}$ & $\begin{array}{l}\text { Uang } \\
\text { Muka }\end{array}$ & $\begin{array}{c}\text { Cicilan Per } \\
\text { Bulan Sesuai }\end{array}$ & Pajak dan Biaya & & & \\
\hline \multirow[b]{2}{*}{ BIP } & Jumlah & 132 & 126 & 146 & 138 & 134 & \multirow[b]{2}{*}{3.38} & 133 & 125 & 143 & 152 & 142 & \multirow[b]{2}{*}{3.48} & \multirow{2}{*}{$97 \%$} & \multirow{2}{*}{$32 \%$} \\
\hline & Rata 2 & 3.30 & 3.15 & 3.65 & 3.45 & 3.35 & & 3.33 & 3.13 & 3.58 & 3.80 & 3.55 & & & \\
\hline \multirow{2}{*}{ Palumbon } & Jumlah & & & 139 & 140 & 148 & \multirow[b]{2}{*}{3.49} & & & & & & \multirow{2}{*}{3.44} & \multirow{2}{*}{$101 \%$} & \multirow{2}{*}{$34 \%$} \\
\hline & & & & & & 3.7 & & & & & & & & & \\
\hline \multirow{2}{*}{ Griya Indah } & Jumlah & & & 143 & & 12 & \multirow[b]{2}{*}{3.42} & & & & & & \multirow{2}{*}{3.32} & $103 \%$ & \multirow{2}{*}{$34 \%$} \\
\hline & Rata 2 & & 3.2. & & 3. & 3 & & & & & & & & & \\
\hline Gabungan & \begin{tabular}{|l|} 
Total \\
Rata 2
\end{tabular} & $\begin{array}{l}409 \\
3.41\end{array}$ & $\frac{393}{3.28}$ & $\begin{array}{l}428 \\
3.57\end{array}$ & $\frac{45}{3.46}$ & $\frac{411}{3.43}$ & 3.43 & 30 & 30 & 424 & 3.73 & $\frac{412}{3.43}$ & 3.41 & $100 \%$ & $100 \%$ \\
\hline
\end{tabular}


Dari seluruh responden, rata-rata nilai TKI faktor harga sama dengan $100 \%$. Hal ini menunjukan konsumen puas terhadap strategi harga di ketiga perumahan tersebut. Namun, untuk Perumahan Griya Indah memiliki angka TKI di atas rata rata yaitu 103\%, lebih besar dari rata rata TKI di ketiga perumahan yaitu 100\%. Ini berarti secara harga yang ditawarkan Griya Indah lebih baik di mata konsumen dibandingan kedua perumahan lainnya.

Tabel 7. Analisa Gabungan TKI untuk Faktor Lingkungan

\begin{tabular}{|c|c|c|c|c|c|c|c|c|c|c|c|c|c|c|c|}
\hline \multirow{2}{*}{\multicolumn{2}{|c|}{$\begin{array}{c}\text { Faktor Kondisi } \\
\text { Lingkungan }\end{array}$}} & \multicolumn{5}{|c|}{ Tingkat Kepuasan } & \multirow{4}{*}{\begin{tabular}{|c|}
$\begin{array}{c}\text { Rata } \\
\text { RataTingkat } \\
\text { Kepuasan }\end{array}$ \\
3.13 \\
\end{tabular}} & \multicolumn{5}{|c|}{ Tingkat Kepentingan } & \multirow{4}{*}{\begin{tabular}{|c|}
$\begin{array}{c}\text { Rata Rata } \\
\text { Tingkat } \\
\text { Kepentingan }\end{array}$ \\
3.07 \\
\end{tabular}} & \multirow{4}{*}{$\begin{array}{c}\text { TKI } \\
102 \% \\
\end{array}$} & \multirow{4}{*}{\begin{tabular}{|c|} 
Bobot (\%) \\
$33 \%$ \\
\end{tabular}} \\
\hline & & \multirow{3}{*}{$\begin{array}{r}\begin{array}{c}\text { Keamanan } \\
\text { Lingkungan }\end{array} \\
144 \\
3.60 \\
\end{array}$} & \multirow{3}{*}{\begin{tabular}{|r|}
$\begin{array}{c}\text { Lingkungan } \\
\text { Asri dan } \\
\text { Nyaman }\end{array}$ \\
127 \\
\end{tabular}} & \multirow{2}{*}{\begin{tabular}{|}
$\begin{array}{c}\text { Lahan } \\
\text { Perumahan } \\
\text { Luas dan Jalan } \\
\text { Lebar }\end{array}$ \\
119 \\
\end{tabular}} & \multirow{2}{*}{\begin{tabular}{|r|}
$\begin{array}{c}\text { Perumahan } \\
\text { Sudah Ramai }\end{array}$ \\
120 \\
\end{tabular}} & \multirow{3}{*}{\begin{tabular}{|r|}
$\begin{array}{c}\text { Tetangga } \\
\text { Perumahan } \\
\text { Dikenal Baik }\end{array}$ \\
115 \\
2.88 \\
\end{tabular}} & & \multirow{3}{*}{$\begin{array}{r}\begin{array}{c}\text { Keamanan } \\
\text { Lingkungan }\end{array} \\
145 \\
3.63\end{array}$} & \multirow{2}{*}{\begin{tabular}{|r|}
$\begin{array}{c}\text { Lingkungan } \\
\text { Asri dan } \\
\text { Nyaman }\end{array}$ \\
135 \\
\end{tabular}} & \multirow{2}{*}{\begin{tabular}{|c|c|c|}
$\begin{array}{c}\text { Lahan } \\
\text { Perumahan } \\
\text { Luas dan Jalan } \\
\text { Lebar }\end{array}$ \\
120 \\
\end{tabular}} & \multirow{2}{*}{\begin{tabular}{|r|}
$\begin{array}{c}\text { Perumahan } \\
\text { Sudah Ramai }\end{array}$ \\
117 \\
\end{tabular}} & \multirow{3}{*}{\begin{tabular}{|r|}
$\begin{array}{c}\text { Tetangga } \\
\text { Perumahan } \\
\text { Dikenal Baik }\end{array}$ \\
96 \\
2.40 \\
\end{tabular}} & & & \\
\hline BIP & Jumlah & & & & & & & & & & & & & & \\
\hline$B \mid P$ & Rata 2 & & & 2.98 & 3.00 & & & & 3.38 & 3.00 & 2.93 & & & & \\
\hline Palumbon & Jumlah & 145 & 142 & 123 & 118 & 136 & 3.32 & 143 & 141 & 117 & 115 & 109 & 3.13 & $106 \%$ & $34 \%$ \\
\hline & Rata 2 & 3.63 & 3.55 & 3.08 & 2.95 & 3.40 & & 3.58 & 3.53 & 2.93 & 2.88 & 2.73 & & & \\
\hline Griya Indah & $\frac{\text { Jumlah }}{\text { Rata 2 }}$ & $\begin{array}{r}144 \\
3.60\end{array}$ & $\begin{array}{r}127 \\
3.18 \\
\end{array}$ & $\begin{array}{r}119 \\
2.98\end{array}$ & $\begin{array}{r}99 \\
2.48\end{array}$ & $\frac{115}{2.88}$ & 3.02 & $\begin{array}{r}132 \\
3.30\end{array}$ & $\begin{array}{r}126 \\
3.15 \\
\end{array}$ & $\frac{112}{280}$ & $\frac{111}{278}$ & $\begin{array}{r}115 \\
2.88\end{array}$ & 2.98 & $101 \%$ & $33 \%$ \\
\hline Gabungan & Total & 433 & 396 & 361 & 337 & 366 & 3.16 & 420 & 402 & 349 & 343 & 320 & 3.06 & $103 \%$ & $100 \%$ \\
\hline & Rata 2 & 3.61 & 3.30 & 3.01 & 2.81 & 3.05 & & 3.50 & 3.35 & 2.91 & 2.86 & 2.67 & & & \\
\hline
\end{tabular}

Dari seluruh responden, rata-rata nilai TKI faktor lingkungan di atas $100 \%$, yaitu $103 \%$. Ini menunjukan konsumen puas terhadap lingkungan di ketiga perumahan tersebut. Namun, Perumahan Taman Palumbon Asri memiliki angka TKI di atas rata rata yaitu 106\%, lebih besar dari rata-rata TKI di ketiga perumahan. Ini berarti lingkungan yang ditawarkan Taman Palumbon Asri lebih baik di mata konsumen dibandingan kedua perumahan lainnya.

\section{KESIMPULAN}

Menurut preferensi responden, faktor penentu kepuasan konsumen dalam pengambilan keputusan pembelian yang sangat penting adalah Faktor Lokasi dan Harga, kemudian diikuti Faktor Lingkungan serta Desain dan Kualitas Bangunan. Dari temuan dan analisa penulis, Faktor Lokasi dan Harga merupakan mutlak sebagai penentu pengambilan keputusan. Sedangkan, kesimpulan masing-masing perumahan adalah sebagai berikut.

\section{Bhumi Indah Persada}

Bhumi Baru Indah Persada mempunyai nilai TKI di bawah 100\%, yaitu pada faktor lokasi (94\%) dan harga (97\%). Skoring kedua faktor tersebut lebih rendah daripada skoring rata-rata di ketiga perumahan. Artinya, menurut preferensi konsumen yang tinggal disana, mereka kurang puas dengan kedua aspek tersebut.

\section{Taman Palumbon Asri}

Secara keseluruhan, Taman Palumbon Asri mempunyai nilai TKI di atas nilai rata-rata. Pada faktor lokasi $105 \%$, faktor desain dan kualitas bangunan $108 \%$, dan harga $101 \%$, serta lingkungan $106 \%$. Artinya, menurut preferensi konsumen yang tinggal disana mereka sangat puas dengan keempat aspek tersebut.

\section{Griya Indah}

Griya Indah mempunyai nilai TKI di bawah rata-rata, yaitu pada faktor lokasi (88\%) dan faktor lingkungan (103\%). Untuk faktor lokasi, nilai rata-rata TKI di 3 perumahan adalah $96 \%$ dan faktor harga $104 \%$. Artinya, menurut preferensi konsumen yang tinggal disana mereka kurang puas dengan lokasi dan lingkungan perumahan tersebut.

Secara keseluruhan, Perumahan Taman Palumbon menempati posisi pertama yang paling memenuhi ekspektasi konsumen terhadap keempat faktor penentu keputusan pembelian. Perumahan Bhumi Indah Persada menempati urutan kedua, dan Perumahan Griya Indah menempati urutan buncit. Developer Perumahan Taman Palumbon Asri cukup mempertahankan 
kinerja. Sedangkan, developer Bhumi Indah Persada dan Griya Indah harus berbenah dengan meningkatkan faktor-faktor yang belum memenuhi ekspektasi konsumen, sesuai yang sudah dilakukan penulis pada Analisa Kuadran Likert.

\section{DAFTAR PUSTAKA}

Abadi, Adib. 2001. "Menuju Lingkungan Perumahan Perkotaan yang Berkualitas".

A. Parasuraman, Leonard L.Berry, and Valerie. 1985. A Conceptual Model of Services Quality And Its Implication for Future Research. Journal of Marketing, Vol. 49, P.41-50.

Budiharjo, Eko. 1984. Sejumlah Masalah Permukiman Kota. Bandung

Doxiadis, C.A. dan Hill, McGraw. 1996. Time-Savern Standards for Urban Design.

Effendi. 1996. "Analisa Lima Faktor Terhadap Pembelian Rumah Sederhana dan Sangat Sederhana”.

Evans, Alan W.1985. Trade off Theory.

Erawan, Anton. 2012. Pembangunan Perumahan dan Permukiman di Indonesia.

Jakarta (2016). Direktorat Jenderal Pembiayaan Perumahan. URL: http://pembiayaan.pu.go.id/berita/52/kpr-sejahetra-flpp-masih-tetap-dapat-dinikmati$m b r$ (Akses Terakhir: 19 Maret 2017).

Jakarta (2015). Perumahan/Landed House. URL:http//perumnas.co.id/ (Akses Terakhir:19 Maret 2017).

Keputusan Menteri Permukiman dan Prasarana Wilayah RI No. 403/KPTS/M/2002 tentang Pedoman Teknis Pembangunan Rumah Sehat.

Kottler, Philip, dan Kettler, Kevin Lane. 2009. Manajemen Pemasaran Jilid I, Edisi Ketiga Belas, Terjemahan Bob Sabran, MM., Jakarta: Penerbit Erlangga.

Likert, R. 1932. A Technique for Measurement of Attitudes Archives of Psychology, 140, 5-55

Mankiw, N. Gregory. 2004. Principles of Macroeconomics (3 ${ }^{\text {rd }}$ Edition). Thomson, South Western.

Marek, Eddy Leks. 2013. Pusat Perencanaan Pembangunan Hukum Nasional Badan Pembinaan Hukum Nasional Kementerian Hukum dan Hak Asasi Manusia: Analisis dan Evaluasi Peraturan Perundang-Undangan Tentang Perumahan Rakyat, Jakarta.

Martilla and James. 1977. Importance Performance Analysis. Journal of Marketing, Vol. 41, P.77.

McDonald and Rabinowitz. 1989. Urban Economics and Real Estate Theory and Policy. Blackwell Publishing, USA.

Miles, E.m., Barens, L.G., Eppli, J.M., Weiss, A.M. 2007. Real Estate Development and Principles. Urban Land Institute.

Murwanti, Sri. 2009. Perilaku Konsumen dalam Memilih Perumahan pada Perumahan Cipta Laras Bulusulur Wonogiri. Jurnal Manajemen Bisnis Vol. 13.

O'Sullivan, Arthur, 2012. Urban Economics ( $8^{\text {th }}$ Edition). The Mcgraw-Hill Irwin, New York.

Peraturan Menteri Keuangan 113/PMK.03/2014 tentang Perubahan Keempat atas Peraturan Menteri Keuangan No. 36/PMK.03/2007 tentang Batasan Rumah Sederhana, Rumah Susun Sederhana yang dibebaskan dari pengenaan PPN.

Permen PU No. 14 Tahun 2010 tentang Standar Pelayanan Minimal Bidang Pekerjaan Umum dan Penataan Ruang.

Prakoso, Hario. 2015. Faktor Keberhasilan Relokasi Permukiman Menurut Persepsi Penghuni (Studi Kasus: Program Relokasi Pemukiman DAS Bengawan Solo Surakarta). Digital Library Universitas Sebelas Maret.

Roscoe, J. T. 1975. Fundamental Research Statistics for the Behavioral Sciences, 2nd ed. New York: Holt, Rinehart and Winston.

Spiro, Kostof. 1991. The City Shaped; Urban Patterns and Meanings Through History, New 
York: Little, Brown, and Company.

Thunen and Tarigan. 2005. The Isolated State.

Undang-Undang Republik Indonesia Nomor 4 Tahun 1992 tentang Perumahan dan Permukiman. 